\title{
NEEDS ANALYSIS FOR ENGLISH TEACHING/ CURRICULUM DEVELOPMENT IN INDONESIAN SENIOR HIGH SCHOOLS
}

\author{
Risuli Hutauruk ${ }^{1}$ \\ SMAK 1 Penabur Jakarta ${ }^{1}$ \\ risuli.hutauruk@bpkpenaburjakarta.or.id
}

\begin{abstract}
APA Citation: Hutauruk, R. (2020). Needs analysis for English teaching/curriculum development in
\end{abstract} Indonesian senior high schools. Language Research in Society Journal, 1(1), 18-26.

Received: 23 March 2020

Accepted: 06 April 2020

Published: 02 May 2020

\begin{abstract}
Although Indonesian students have learnt English for 6 years when they graduate, there are still many of them who cannot speak the foreign language. One of the important factors which must be taken care of is the syllabus or curriculum of teaching English. The syllabus should be prepared in such a way so that it can match the needs of the students and, in the end, can function well to make students able to speak English when they graduate. A small research has been made to find the target situation analysis, objective needs analysis, subjective needs analysis and present situation analysis (Dudley-Evan \& St. John, 1998). The respondents of the research are students from private and government senior high schools. All the respondents belong to Gen $\mathrm{Z}$, who are used to using digital tools and the internet in their daily life. The results show that Gen Z prefers to use digital tools in learning English at school. This study is expected to propose a syllabus design which deploys technology or digital tools in teaching.
\end{abstract}

Keywords: English; lesson; curriculum; syllabus; gen z; senior high school

\section{INTRODUCTION}

Ever since the Dutch colonization in Indonesia, English has been taught to Indonesian students, but the lesson was banned during the Japanese invasion. After the declaration on the country's independence, the Indonesian government returned the English lesson into the curriculum. $\mathrm{Mr}$ Wachendorf, the first person who chaired the language teaching centre in Indonesia, believed that learning English, the first international language, is important for all Indonesian children, and he decided to put English in the curriculum as one of the compulsory lessons for middle school students (junior and senior high schools). It was then supported by the ministerial decree No. 096/1967.

In order to develop education in Indonesia, the government has revised the curriculum after some period of time. In the curriculums of 1946, 1953, 1962, 1968, 1975, 1984, 1994 for junior high school students, and 1950, 1962, 1968, 1975, 1984, 1994 for senior high school students, it was stated that the final goal of learning English is to get competence in the skills of reading, listening, writing, and speaking. However, in the curriculums of 1984 and 1994, it was stated that the priority of the teaching of English is to make students able to read, listen, speak, and write in English. (Komaria, 1998). The earlier curriculum makers believed that writing was more important than speaking at that time, perhaps because, not many foreigners were there yet; while the new curriculum expected the students to speak English more than to write in English, perhaps, because more and more tourists and expatriates had come to the country. Therefore, the graduates of the later curriculum were expected to be able to talk with foreigners. 
After 1994, the educational curriculum has been revised again for a few times, i.e. in years of 2004, 2006, 2013, and 2016. In 2016, actually, the curriculum 2013 was not changed but revised a little in order to make the curriculum 2013 can be more acceptable and executable by schools, teachers, and students. The revision, according to Wiguna (2020), has improved the on-going curriculum in terms of (1) responsibility of evaluation of spiritual and social competence; (2) the coherence of core competencies; (3) opportunities for teacher to be more creative; and (4) opportunities for students' competence taxonomies. All this makes this curriculum 2013 allow the presence of friendlier education and schooling which can develop students better because it encourages students to develop their spiritual, social competence, as well as their knowledge and creativity. It also opens an opportunity for teachers to be more creative, so teachers are not bound to use certain techniques and methods in teaching; they can improvise their lessons based on the condition of the class.

In terms of English syllabus, the curriculum 2013 for SMA students puts stress in developing students' competence so that they can understand and use the language in different contexts, orally and written, with higher complexity than the materials for SMP students. This curriculum uses the text-based approach. Text in this term is any unit of word(s), for example, the word 'stop' on the sideways, phrase 'no smoking', a paragraph of announcement, a long essay, or a book. This makes the genre-based teaching method relevant to teach English by using this curriculum. In delivering the lessons, teachers pick the materials based on genres or text-types, such as narrative, recount, exposition, discussion, etc. Which grade learns which genre has been decided in the syllabus of the curriculum.

This text-based approach in curriculum 2013 also encourages students to study other subjects within the curriculum. While studying the text Explanation, for example, the students can also learn facts or data which are used in Biology, Chemistry, etc. Students can search for more information about plants on the internet, for instance, by reading texts about plants which are mostly in the format of expository texts. Another example is that, when learning descriptive texts, students can also practice promoting Indonesian tourism. (Kebudayaan, 2016)

The purpose of the curriculum is to make students analyze the texts they are reading in terms of content and structure. The content or the message of the text can be used to broaden their knowledge, and the structure of the text can help them understand the language and the message in the text easier. When students realize the structure of a text, they would easily understand the main purpose of the writer in writing the text.

In the beginning, not all schools had to use curriculum 2013; schools which were not ready to apply the curriculum, due to the condition of the students, teachers, and facilities, were allowed to use the old curriculum. However, more and more schools have applied the curriculum 2013 in their teachings. Considering that students who started using the curriculum in 2013 in grade 10 graduated in 2016, until today we have graduated four generations of students who had been taught by using curriculum 2013, i.e. in 2016, 2017, 2018, and 2019. Although they had been taught by using the newest curriculum, there are many students who still cannot speak English nor even understand the foreign language, and it happens within the era of information technology, where English is found in many sources and medias used, like the internet, YouTube, online games, social media, movies, and songs.

Students nowadays are members of Gen Z, who were born from 1995-2010. They are digital natives who have been exposed to the internet, social networks, and mobile systems. This condition makes them a hypercognitive generation who are accustomed to collecting and crossreferencing many sources of information. They are also comfortable with integrating virtual and offline experiences (McKinsey, 2018). From the internet, the students can get a lot of information with different approaches which are interesting and often very different from how 
they get information at school. At schools, often teachers use the same old techniques again and again because they have felt comfortable in it and do not want to get out of their comfort zone. Many teachers do not realize that they have to change their ways of teaching because what they have been doing is no longer relevant to the students' condition.

In fact, the needs for change in the syllabus during a course is something natural because there is a possibility that the learners' needs change during the course. (Richterich and Chancerel, 1978) in Chamber (1980: 27) mention that this may be to due to factors: 1) extraneous to the language learning situation (e.g., shortage of funds from the sponsor) 2) inherent to the learner (e.g., lack of ability or change of interests) 3) resulting from misjudgment/error in the original analysis.' (Chamber, 1980)

The needs for change are very possible especially in this interruption era, in which everything can change abruptly, and so can the way students value studying. The information on the internet and social media show abundant new things and ideas of how people acquire knowledge and practice their skills. This, of course, has affected the students' point of view about learning and studying English. They learn English while they are watching YouTube or playing on-line games with other players in different parts of the world. Listening to the audio or communicating with other people from different countries force them to understand the language and even use it.

Among the students, actually, some students use English as if it were their native language; they sound very fluent in English and look more comfortable using it when talking with their close friends. These students speak Bahasa Indonesia to their teachers and other students in classes during lessons, but when they chit-chat with their close friends, they often mix Bahasa Indonesia with English.

Considering the fact that there are students who can speak English fluently while others cannot understand the language even though they both are taught using the same curriculum, we can conclude that there must be a reason why this happens or how to make all the students able to speak English by the time they have graduated from their senior high school. We need to analyze how the English classes go on in senior high schools, or we need to find out what the English speaking students have done or experienced so that they could have good command on English, and at the end, we might have some proposed improvised procedure in teaching English in class. According to Richards (2001) there are three dimensions of procedure: (a) the use of teaching activities, (b) the ways in which particular teaching activities are used for practicing language; and (c) the procedures and techniques used in giving feedback to learners. So, we hope, in the end, this study might propose a new procedure which can give students better experience in learning English in class.

\section{METHOD}

At the beginning of curriculum development, the curriculum for language teaching was developed based on language analysis, beginning with the specification of what was teachable and learnable based on such criteria as frequency, difficulty, availability and teachability, current approaches to language curriculum development begin with needs analysis or needs assessment. (Richards, Language Curriculum development, 1984).

In order to find out reasons why some students can speak English a lot better than the others, the writer has done research by asking 105 students from two schools, i.e. one state school and one private school, to fill in an on-line questionnaire. The results or the responses were then analyzed qualitatively as to search for the richest possible data. In this method it is recognized that the ideas and presence of researchers will be influential in what the data looks like and the way in which it is interpreted. (Paltridge, 2015). However, with all respects, the writer believes 
that how the method has been done is not fully driven by the writer's wants but based on what has been found in the field based on the writer's 20-year experience as a teacher, because the writer has found that students have become less interested in learning English at school, so the writer made a set of questions asked to students. Not only students in the private school in Jakarta where the writer is teaching, other students from a state school in Jakarta were also asked the same questions.

To make it easy, the questions were asked on-line. The writer gave the link to her own students and shared it with a teacher in the government school who then shared it with her students. The number of students who submitted the answers were 105 students from both schools.

Below are the questions asked:

1. Do you think English is important?

2. In your opinion, what makes English important?

3. Do you think learning English at school is important for SMA level students?

4. What do you want to learn in English subject at SMA?

5. What can help you acquire or learn English? (anywhere)

6. What can help you acquire or learn English at school?

7. How should English be taught in SMA?

8. Are you satisfied with your English competence now?

9. What is your friends' evaluation about your English competence?

10. What is the challenge of learning English in SMA?

11. In 10 minutes, write a paragraph about how you have been acquiring or learning English.

\section{FINDINGS}

As quoted by Mohajan (2018), Zohrabi (2013) says that qualitative research is used to understand the social reality of individuals. It can be done by deploying interviews, diaries, journals, classroom observations and immersions; and open-ended questionnaires to obtain, analyze, and interpret the data content analysis of visual and textual materials, and oral history. Mohajan (2018) also quoted Brink (1993) saying that qualitative researchers are interested in people's belief, experience, and meaning systems from the perspective of the people. Therefore, in this research, the data will be related to the students' belief and experience in acquiring English and what can help them or other students improve their English competence.

From all the 105 students' responses, we can understand that all of the students find that English is important because English is an international language which can be useful to communicate with other people in social media. They also realize that English is useful in their future when they study abroad or work with people from other countries, and all of the responding students are sure that English must be taught at SMA level. They still need to learn English in SMA.

For the question 'What do you want to learn in English subject at SMA?' the responses vary a lot. However, many students consider that they need to learn grammar because they want to use correct grammar English. They understand that when they are to continue their study abroad, they need to be able to use correct grammar in order to pass the required test. However, not all students need to learn grammar, and few students consider that grammar should have been mastered when they were in junior high schools; what they need to learn in SMA are reading and writing skills, which they most likely find in the university later on.

They also wish that they could learn how to speak English as naturally as the native speakers do because they realize that how they speak English is not the same as how the native speakers speak the language. They can compare how they speak the language with other students in their 
class when they communicate. Some of their friends sound very fluent, and they want to have the same competence.

Mostly the students have started learning or being exposed to English since they were kids. They learn from their parents, from movies, songs, comic books, internet, and TV serials. At schools, the students learn English by communicating with their friends, teachers, reading textbooks, Google, and YouTube. They are quite lucky because their teachers sometimes allow them to access the internet for English materials. The average Gen Z started using their private smartphone before their twelfth birthday. Mostly they communicate through social media and texts and spend much time on their phones. They also prefer using streaming services to traditional cable. (Insider, 2019)

In answering the question 'How should English be taught in SMA?', the students answered that they want fun methods in learning English. They hope technology will be used in learning English because technology opens the door to many new applications which can be interesting to students, so they expect to be able to use the internet and gadgets while learning. Using the internet and gadgets can be interesting and useful for the students because they can get many English texts and audios on the internet. Not only getting input from the internet, the students also hope to have an opportunity to practice English with the teachers and the other students. Mostly the internet and other media only give them input but not a chance to practice. Thus, according to the students, they lack time to practice English. They wish they could have more opportunities at school practicing English with their peers and teachers. When they have the chance to speak English with another person, they have a chance to improve their English competence.

Among the students' answers, there are students who expect to have more tests in class in order to spur them to study English. Tests are often a nightmare for students, but most of them force themselves to study harder when tests are coming. Therefore, tests or quizzes should also be considered important in an English class. However, when asked about the challenge they experience in learning English, many of the students feel uncomfortable in learning tenses. Although many of the students consider that they can understand and speak English, they consider that learning tenses is boring and stressful.

For the last question, writing a paragraph about how they have been acquiring or learning English, most of the students wrote that they have been acquiring English since they were very little by watching movies and listening to English songs. When they are bigger, they watch movies with English subtitles, where they learn English vocabulary. Listening to the English words while reading the subtitles, they can associate the spelling and the sound, and also the meaning. This makes them understand the words better and memorize them.

Some other students take extra lessons, like IELTS class, to help them practice English with native speakers because they do not speak English with the members of the family at home. These students take IELTS classes also because they wish to continue their study abroad. Joining an IELTS class will help them prepare for the IELTS test, which is often required by universities abroad when students are applying there.

Among the respondents, there are students who became motivated to learn English because of social media. For example, a student who was not very interested in learning English followed an Instagram account of a cartoon movie and found out that the followers are people from different countries and they use English to make comments or to communicate with each other. This made the student realize that he needed to understand English, and then he started to learn the language better. 


\section{DISCUSSION}

Richards (1984) said that, in language teaching development, there are a lot of studies on the nature of language syllabuses, on teaching method, on testing and on needs analysis, and this study should contribute to them.

As an international language, English should be understood by people in the world, including Indonesia, and therefore, it has to be mastered by students in the country. The government has made their effort to make the people master English by making English a compulsory lesson for all students of junior and senior high schools in Indonesia. English has been one of the compulsory lessons in the curriculum since 1946. However, although the curriculum has been revised many times in order to make the lessons more effective, not many high school graduates can speak English well. That means that there must be something wrong with the curriculum or English syllabus, especially. The faulty can be in the planning, or the execution of the lessons at schools, or other reasons. Our focus in this study is to find a solution to that problem by getting students' responses to how they have acquired English, especially those who have succeeded in learning English.

The students nowadays, Generation Z, they always search for truth in both a personal and a communal form. This generation feels comfortable to find freedom of expression and openness to understanding different kinds of people. (McKinsey, 2018)

Among the responses obtained through an online questionnaire, mostly, those who have successfully learned acquired English have not got the skills from the English lessons at school. They got their competence from other sources and occasions, such as watching TV, watching movies, listening to songs, reading books, social media, online games, and even taking an IELTS class. All these are rarely found in Indonesian English classes. The reasons are many. For example, there are so many targets that have to be accomplished by the teachers in the curriculum while the allocated time for the English lesson is only two hours a week $(2 \times 45$ minutes a week). Although the newest curriculum has opened doors for teachers to modify their lessons, the limited time is surely one of the obstacles for the teachers to modify their lesson. Yet, in case we cannot do anything with the time allocation, there might be other ways that we can help solve the problem. Modifying the curriculum or the syllabus, hopefully, can help students learn English better.

Based on students' responses, we can conclude that students need to get a lot of input before they can produce a language. Some teachers who have a lot of recorded materials will have little problems in giving students opportunities to listen or watch English songs and movies. However, English recorded materials are often expensive and boring for young students. The materials could have been used since years ago, and the graphics of the movies are often lower than what can be found on the internet or students' gadgets. This makes the youngsters nowadays find it boring watching English recorded materials because English materials in the form of videos and songs from YouTube, or English chats in social media are more interesting and, thus, more effective because they are quite up-to-date to students' environments.

Another thing that must be paid attention to, based on students' preferences, is the use of technology and the internet-using technology when teaching can help teachers provide the materials with different techniques which are attractive to students. Actual materials are also helpful because students will find the essence of learning when they get real and up-to-date information. They will find learning English important because it can be used to get recent news and can help them catch up with the real situation in the world. By using materials that are 
found on the internet, the teachers and students can choose the materials which suit students' needs and wants.

The way the students do the exercises needs to be fun and interesting. Online games and other entertainments have given students experiences to fun activities. Thus, learning a lesson in conventional ways must be torturing for the students. Therefore, teachers are supposed to provide more interesting and challenging lessons; they can use games, quiz in the class, or even projects which relate students within a class, a school, or even in different schools. This kind of activity will challenge students to do their best and be more creative in doing their tasks. This collaborative learning is also a good technique to help students socialize or interact with other people.

Finally, the students also need to practice their English, so they need to speak to another person or other people to practice their English. It is the task of the teacher to give students a chance to speak English during class, so, especially for the schools which cannot provide native teachers, the class teacher should be the only source for the students to practice English. The teacher could be the partner of the students in speaking English. Perhaps, in some classes where the number of students is large, the teachers should modify the lesson to make every student have an opportunity to practice their English. Not only practice English with the teacher, but students could also be assigned to practice with other students with instructions from the teacher.

\section{CONCLUSION}

Although the newest curriculum, Curriculum 2013, has graduated many students from senior high schools, not all the students are able to speak English all over Indonesia. This makes the six-year studying English in junior and senior high schools look useless. Therefore, correction or revision to the curriculum or syllabus should be committed.

Based on the discussion above, in order to make English teaching effective in senior high schools, we can conclude that there must be a change in the curriculum or syllabus for English lessons. The new era of disruption which deploys new technology, has forced people, especially the young ones, to change and adapt to the new era. In this era, everyone must deal with abrupt changing. This also gives impacts on students' way of learning things. Therefore, the school system needs to change, too.

After doing a small study through an on-line questionnaire, it can be concluded that we need to revise the way of teaching English in Indonesia. The change is needed especially in the procedure of the teaching in the classroom. Therefore, this study would suggest an improvement in the Indonesian curriculum, especially the English syllabus. The improvement would be as follows.

In one year an English class can have about 30 meetings of 2 times 45 minutes. Within one year there are about 10 topics that have to be learned by the students. Therefore, in one year, the teacher needs to modify their teaching and allocate the time for lessons which use a better approach.

Based on the research, there are things that can make the lessons more beneficial for the students, i.e.

1. Watching related materials from YouTube

2. Quiz on-line

3. Online games

4. Homework: watching an English movie on TV 

5. Use PPT
6. Watch videos with English subtitle
7. Listen to English song
8. Do a project with other students
9. Talk with a native speaker
10. Project using social media
11. Find related texts on the internet
12. Practicing IELTS questions

Perhaps, for some teachers, who are not used to modifying their teaching, it is difficult for them to decide when to use the technology in their teaching. Therefore, if the syllabus could state it clearly, all teachers would find it easier to teach by using technology.

Below is an example of how syllabus can be modified. The topic for each meeting is not decided here. This is only an example of how the technology can be used for each meeting. The order is not a must either. For example, the use of video can be in the first meeting, second, third, etc. The main point is that every meeting or every topic, there must be one or two or three uses of technology. Teachers should not just let the children finish one topic without deploying any technology. For the students, being able to use their gadgets while studying is very enjoyable. This will make them engaged in the lesson and make them understand the lesson better. Below is an example of the use of technology in English lessons:

\begin{tabular}{|c|c|}
\hline MEETING 1 & $\begin{array}{l}\text { Introduction to the syllabus and all members of the class. (This is } \\
\text { important to make every student engaged to the class) }\end{array}$ \\
\hline MEETING 2-4 & Learn Topic 1 by using a video \\
\hline MEETING 5-7 & $\begin{array}{l}\text { Learn Topic } 2 \text { by using an assignment which requires students to } \\
\text { watch English films on TV and have Quiz On-line }\end{array}$ \\
\hline MEETING 8-10 & Learn topic 3 by using social media and on-line games \\
\hline MEETING 11-13 & $\begin{array}{l}\text { Learn topic } 4 \text { by listening or talking to a native speaker and have } \\
\text { on-line test }\end{array}$ \\
\hline MEETING 14-16 & Learn topic 5 by using PPT \\
\hline MEETING 17-19 & $\begin{array}{l}\text { Learn topic } 6 \text { by using Students' PPT, getting related texts in the } \\
\text { internet }\end{array}$ \\
\hline MEETING 20-22 & Learn topic 7 by using YouTube \\
\hline MEETING 23-25 & Learn topic 8 by using IELTS questions \\
\hline MEETING 26-28 & $\begin{array}{l}\text { Learn topic } 9 \text { by doing a project in collaboration with other } \\
\text { students. }\end{array}$ \\
\hline MEETING 29-31 & Learn Topic 10 by using an English song \\
\hline
\end{tabular}

However, some teachers might have problems with internet connections, due to the distance of the schools, especially those which are located in remote areas, or the high price of the internet, which cannot be afforded by some schools. This, of course, needs attention from the government. An incentive for internet connection should be provided by the government for each school in order to help students and teachers have an internet connection at schools.

\section{REFERENCES}

Chamber, F. (1980). A re-evaluation of needs analysis in ESP. ESP Journal, 25-33.

Dudley-Evans, T. (1998). English for Specific Purposes. Cambridge University Press. 
Insider, B. (2019). Generation Z latest characteristics, research, and facts. Retrieved from Business Insider: https://www.businessinsider.com/generation-z?IR=T

Insider, B. (n.d.). Generation Z Latest $c$.

Kebudayaan, K. P. (2016). Silabus Mata Pelajaran Sekolah Menengah Atas/Madrasah Aliyah/ Sekolah Menengah Kejuruan/ Madrasah Aliyah Kejuruan (SMA/ MA/ SMK/MAK). Kementrian Pendidikan dan Kebudayaan.

Komaria, O. (1998). English language teaching - History. Atma Jaya.

McKinsey. (2018, November). 'True Gen': Generation $Z$ and its implications for companies. Retrieved from McKinsey \& Company: https://www.mckinsey.com/industries/consumer-packaged-goods/our-insights/truegen-generation-z-and-its-implications-for-companies\#

Mohajan, H. (2018). Qualitative research methodology in social sciences and related subjects. Journal of Economic Development, Environment and People, 7(1), 23-48.

Paltridge, B. (2015). Research methods in applied linguistics. Bloomsbury.

Richards, J. C. (1984). Language curriculum development. RELC JOURNAL, 15(1), 2-29.

Richards, J. C. (2001). Approaches and methods in language teaching. Cambridge University Press.

Wiguna, J. (2020, March 10). Quipper.com. Retrieved from Quipper.com: Quipper.com/id/blog/tips-trick/penerapan-kurikulum-2013-revisi/ 